\title{
AUTHOR INDEX Volume 4 (1999)
}

Ahmad, T. S., see Siow, Y. S.

2(1999) 167-174

Ang, B. T., see Low, C. K.

1(1999)63-66

Aoki, M., see Wada, T.

2(1999) 117-124

Asami, A., Takayama, G. and Hotokebuchi, T., Pronator Teres Syndrome Associated with Mononeuritis Multiplex in Polyarteritis Nodosa

2(1999) 189-192

Baer Carrie, see Seradge Houshang

Bain, G. I., Clinical Utilisation of Computed Tomography of the Scaphoid

1(1999)91-94

1(1999)3-9

Bain, G. I., Wallwork, N. A., Percutaneous A1 Pulley Release. A Clinical Study

1(1999) 45-50

Becker, C., see Deshmukh, N.

1(1999)87-90

Beppu, M., see Ueno, E.

Beppu, M., see Yoshida, R.

2(1999)159-165

2(1999)109-115

Beyermann, K., Jacobs, C. and Lanz, U., Severe Contractures of the Proximal Interphalangeal Joint in Dupuytren's Disease: Value of Capsuloligamentous Release

1(1999)57-61

Britton, E., see Zavitsanos, G.

1(1999) 51-55

1(1999)11-19

Chen, I.-C., Zhang, G.-M. and Tsai, T.-M., Multiple Entrapment Neuropathy in the Upper Extremity

2(1999)137-144

Chow, S. P., Ip, W. Y. and Poon, T. L., Comminuted Intra-Articular Fracture of the Distal Radius — The Technique of Open Reduction and Internal Fixation with Plating

2(1999) 175-180

Chuang, D. C. C., see Lutz, B. S.

2(1999)131-136

1(1999)11-19

1(1999)87-90

2(1999) 185-188

2(1999) 167-174

2(1999)151-157

1(1999) 51-55

Gupta, A., see Zavitsanos, G.

Gupta, A., Risitano, G., Crawford, R. J. and Burke, F. D., The Ununited Scaphoid: Prognostic Factors in Delayed and Nonunions of the Scaphoid

Herbert, T. J., Introduction

Hirata, K., see Yoshida, R.

Horiuchi, Y., see Nakamura, T.

Hotokebuchi, T., see Asami, A.

Hotta, T., Yamashita, T. and Ogino, T., Solitary Bone Cyst in the Hamate Without Abnormal Findings in Plain X-ray Film - A Case Report

1(1999)11-19

1(1999) 1-2

2(1999)109-115

1(1999)67-73

2(1999) 189-192

2(1999)181-184

Ikeda, K., Yokoyama, M., Okada, K. and Tomita, K., Obstruction of the Radial Artery Passing beneath the Bicepts Brachii Tendon - A Case Report

1(1999)101-103

Ip, W. Y., see Chow, S. P.

2(1999) 175-180 
Ishii, S., see Wada, T.

2(1999) 117-124

Ishii, S., see Yoshida, R.

2(1999) 109-115

Iwasaki, N., see Minami, A.

2(1999) 193-196

Jacobs, C., see Beyermann, K.

1(1999) 57-61

Kang, K. H., see Lee, K. S.

1(1999) 95-100

Kato, H., see Minami, A.

Kato, H., Nakamura, R., Lunate Morphology of Kienböck's Disease on X-Ray Study

Kleinert, H., see Zavitsanos, G.

Koh, W. L., Lim, B. H., Soft Tissue Complications Following Kirschner Wire Fixation for Fusion of Basal Joint Arthritis

Komurai, M., see Ueno, E.

Lanz, U., see Beyermann, K.

Lee, K. S., Lee, S. H., Kang, K. H. and Oh, K. J., Metastatic Hepatocellular Carcinoma of the Distal Phalanx of the Thumb:

A Case Report

Lee, S. H., see Lee, K. S.

Lim, B. H., see Koh, W. L.

Looi, K. P., Low, C. K. and Yap, Y. M., Pigmented Villonodular Synovitis of the Hand in the Asian Population

Low, C. K., see Looi, K. P.,

Low, C. K., Ang, B. T., Herbert Screw Fixation for Scaphoid Fracture

Lutz, B. S., Ma, S.-F., Chuang, D. C. C. and Wei, F.-C., Effects of Systemically Applied IGF-1 on Motor Nerve Recovery After Peripheral Nerve Transection and Repair in the Rate - A Functional Study

Ma, S.-F., see Lutz, B. S.

Minami, A., Kato, H. and Iwasaki, N., Snapping of Triceps Tendon After Anterior Nerve Transposition for Recurrent Subluxation of the Ulnar Nerve

Miyasaka, T.-A., see Nakamura, Y.

Nakagawa, H., see Nakamura, Y.

Nakamura, R., see Kato H.,

Nakamura, T., Yabe, Y. and Horiuchi, Y., Functional Anatomy of the Interosseous Membrane of the Forearm Dynamic Changes during Rotation

Nakamura, Y., Uchiyama, S., Toriumi, H., Nakagawa, H. and Miyasaka, T.-A., Longitudinal Median Nerve Conduction Studies After Endoscopic Carpal Tunnel Release

Ogino, T., see Hotta, T.

Oh, K. J., see Lee, K. S.

Okada, K., see Ikeda, K.

Poon, T. L., see Chow, S. P.

Prachaporn, S., see Wheen, D.

Risitano, G., see Gupta, A.

Robinson, M., see Wheen, D.

Sandow, M. J., Salvage Techniques in Scapoid Nonunion

Seradge Ali, see Seradge Houshang

Seradge Houshang, Tian Wen, Baer Carrie and Seradge Ali, The Posterior Interosseous Nerve Anatomical Variation and Surgical Consideration — A Case Report of Cadaver Dissection

Shimizu, H., see Ueno, E.

Siow, Y. S., Ahmad, T. S. and Goh, S. Y., Use of a New External Fixator for the Correction of Fixed Flexion Deformity of the Fingers

Somia, N., see Zavitsanos, G.

Stahl, S., Freiman, S., Simultaneous Scaphoid and Galeazzi Fractures

Stanley, J. K., see Thurston, A. J.

Takayama, G., see Asami, A.

2(1999) 193-196

1(1999) 75-79

1(1999) 51-55

2(1999) 197-202

2(1999)159-165

1(1999)57-61

1(1999)95-100

1(1999) 95-100

2(1999) 197-202

1(1999)81-85

1(1999)81-85

1(1999)63-66

2(1999)131-136

2(1999)131-136

2(1999) 193-196

2(1999) 145-149

2(1999) 145-149

1(1999) 75-79

1(1999)67-73

2(1999) 145-149

2(1999) 181-184

1(1999)95-100

1(1999) 101-103

2(1999) 175-180

1(1999)21-31

1(1999)11-19

1(1999)21-31

1(1999) 33-40

1(1999)91-94

1(1999)91-94

2(1999)159-165

2(1999) 167-174

1(1999) 51-55

2(1999) 185-188

2(1999) 125-129

2(1999) 189-192 
Tamaki, T., see Taniguchi, Y.

1(1999) 105-107

Taniguchi, Y., Tamaki, T., Malignant Fibrous Histiocytoma of the Digit. A Case Report

1(1999) 105-107

Thurston, A. J., Stanley, J. K., Dowel Fusion of the Scapho-Trapezio-Trapezoid Joint: A Description of a New Technique

2(1999) 125-129

Tian Wen, see Seradge Houshang

Tomita, K., see Ikeda, K.

Tonkin, M. A., Editorial Comment to Symposium

Tonkin, M. A., see Green, J. A.

Toriumi, H., see Nakamura, Y.

Tsai, T.-M., see Chen, I.-C.

Uchiyama, S., see Nakamura, Y.

Ueno, E., Beppu, M., Shimizu, H. and Komurai, M., Bone Lesions of the Hand and Wrist in Patients Undergoing Hemodialysis for Ten Years

1(1999)91-94

1(1999) 101-103

1(1999) 41-43

2(1999) 151-157

2(1999) 145-149

2(1999) 137-144

2(1999) 145-149

2(1999)159-165

Usui, M., see Wada, T.

Visvanathan, S., see Wheen, D.

Wada, T., Aoki, M., Usui, M. and Ishii, S., DISI Deformity and Post-Operative Symptoms of Scaphoid Non-Union

Wallwork, N. A., see Bain, G. I.

Watkins, F., see Zavitsanos, G.

Wei, F.-C., see Lutz, B. S.

Wheen, D., Robinson, M., Prachaporn, S. and Visvanathan, S., Techniques for Vascularised Bone Grafting in Scaphoid Nonunion

Yabe, Y., see Nakamura, T.

Yamashita, T., see Hotta, T.

Yap, Y. M., see Looi, K. P.,

Yokoyama, M., see Ikeda, K.

2(1999) 117-124

1(1999) 21-31

2(1999) 117-124

1(1999) 45-50

1(1999) 51-55

2(1999)131-136

Yoshida, R., Beppu, M., Ishii, S. and Hirata, K., Anatomical Study of the Distal Radioulnar Joint: Degenerative Changes and Morphological Measurement

1(1999)21-31

1(1999)67-73

2(1999) 181-184

1(1999)81-85

1(1999)101-103

2(1999)109-115

Zavitsanos, G., Watkins, F., Britton, E., Somia, N., Gupta, A. and Kleinert, H., Distal Interphalangeal Joint Arthrodesis Using Intramedullary and Interosseous Fixation

1(1999) 51-55

Zhang, G.-M., see Chen, I.-C.

2(1999) 137-144 